\title{
Economic Responsiveness and the Political Conditioning of the Electoral Cycle
}

\author{
Sergi Pardos-Prado, Merton College, University of Oxford \\ Iñaki Sagarzazu, Texas Tech University
}

\begin{abstract}
Understanding the drivers of party issue emphasis and the specific role of public opinion is important to shed light on the mechanisms of contemporary party competition and to assess the quality of representation in liberal democracies. Previous research has produced conflicting results between issue ownership and issue dialogue perspectives and has ignored the role of time in party communication strategy. We present a theory focused on the economy in which proximity to election day increases the incumbent's cost of not responding to opponent attacks and subsequently decreases the incumbent's attention to public opinion. We validate the main empirical implications of the model via content analysis of party discourse in Spanish parliamentary speeches (1996-2011) and time series analyses. Our results have pessimistic implications for an ideal conception of bottom-up representation. As electoral accountability pressures increase over the electoral cycle, endogenous party competition overshadows public opinion as a driver of representatives' agenda.
\end{abstract}

U nderstanding the determinants of parties' issue emphasis has important implications for the quality of representation in liberal democracies, especially at a time of increasing political disaffection, populist success, and an apparent disconnect between mainstream elites and substantial sectors of the public. The drivers of party discourse and their implications for representation have been studied from a variety of angles. Two approaches, however, stand out as the core of such studies. The issue ownership approach is one of the most prominent perspectives, which expect parties to highlight the issues that either benefit them or harm their competitors (Petrocik 1996; Vavreck 2007). However, the empirical evidence of this claim has been contested by an alternative issue dialogue approach, in light of increasing convergence in party communication strategies both in the United States and in multiparty systems (see, e.g., Green-Pedersen and Mortensen 2014; Kaplan, Park, and Ridout 2006; Sagarzazu and Klüver 2017). Among the reasons why parties do not always highlight issues that should theoretically benefit them, some scholars argue for the responsiveness of parties to public opinion (Ansolabehere and Iyengar 1994; Klüver and Sagar- zazu 2016; Spoon and Klüver 2015), their engagement with a broad system issue agenda (Green-Pedersen and Mortensen 2010, 2014), or the powerful role of the media in setting the agenda of political parties (Green-Pedersen and Stubager 2010; Walgrave and Van Aelst 2006).

In this article we argue that the electoral cycle is a decisive determinant of party issue emphasis that helps to understand some of the contradictions between issue ownership and issue dialogue perspectives and the link between public opinion and party agendas. Despite the importance of previous contributions, the conditioning effect of the timing of party messaging strategies usually has been disregarded. The literature on party messaging and issue competition has typically focused on the campaign period (e.g., Kaplan et al. 2006; Petrocik 1996; Spoon and Klüver 2015). Wherever longer time periods have been analyzed (Green-Pedersen and Mortensen 2014), the role of the electoral cycle has been undertheorized and has not been specifically tested. This seems like a pressing research gap, especially given that timing within the electoral cycle has recently been suggested to be important when predicting intracoalition dynamics (Sagarzazu and

Sergi Pardos-Prado (sergi.pardos@merton.ox.ac.uk) is an associate professor in politics at Merton College, University of Oxford, Oxford OX1 4JD, United Kingdom. Iñaki Sagarzazu (inaki.sagarzazu@ttu.edu) is an assistant professor in the Department of Political Science at Texas Tech University, Lubbock, TX 79409. The order of the authors' names is alphabetical; both authors have contributed equally to all work.

Data and supporting materials necessary to reproduce the numerical results in the article are available in the JOP Dataverse (https://dataverse.harvard.edu /dataverse/jop). An online appendix with supplementary material is available at http://dx.doi.org/10.1086/701495.

The Journal of Politics, volume 81, number 2. Published online January 18, 2019. http://dx.doi.org/10.1086/701495

(c) 2019 by the Southern Political Science Association. All rights reserved. 0022-3816/2019/8102-0005\$10.00 
Klüver 2017) and electoral sentiment (Jennings and Wlezien 2016).

We present a theoretical model focusing on the issue of the economy, in which proximity to election day increases the incumbent's cost of not responding to opponents' attacks and the risk of competitors gaining issue ownership. While our focus on the economy may or may not be applicable to other issues with more static patterns of ownership, the economy has been considered as representative in previous influential work in the party-centered literature on issue ownership (Vavreck 2007). Moreover, recent work on issue dialogue increasingly documents patterns of engagement across a variety of issues for which our hypothesized mechanisms could be perfectly applicable. One of the novel implications of our model is that, under certain conditions of party reputation, it is more beneficial for parties to engage in issue dialogue with their competitors close to election day, at the cost of ignoring public opinion. In order to test the conditioning effect of the electoral cycle on economic issue competition strategies, we use a novel data set of party attention to economic issues in Spain (1996-2011) measured at the month level, together with objective macroeconomic indicators and survey data on individual economic perceptions.

Our findings have two important implications for the literature on issue competition and for understanding contemporary political representation. First, we confirm the importance of focusing on government opposition dynamics when analyzing policy representation (Seeberg 2013; Thesen 2013) and show that the electoral cycle strongly affects the incentives of the governing party to respond to the messages of its main competitor. This conditional effect sheds some light on previous controversies between issue ownership and issue dialogue theories. Both types of theory seem to be correct conditional on time and on whether parties are in or out of power. While opposition parties tend to only follow issue ownership strategies, incumbent parties can follow both. At the beginning of the cycle incumbent parties tend to be freer to articulate their economic communication strategy, whereas toward the end of the cycle the pressure to respond to attacks and prevent opposition ownership of the economy is much higher.

Second, the role of public opinion in driving party issue attention seems to be far from the idealistic bottom-up conception of democratic representation. Opposition parties tend to highlight economic issues only on the basis of indirect shortterm reactions to bad macroeconomic conditions that are amplified by the media, while incumbent parties tend to be highly responsive to public opinion only at the beginning of the electoral cycle. As election day approaches, the dynamics of endogenous party competition overshadow the role of public opinion in setting the agenda of representatives.
ISSUE COMPETITION IN PARLIAMENTARY SPEAKING The selective choice of which issues to raise is an important part of a political party's competition strategy. Most of the literature on party issue emphasis has focused on campaigns or election-specific documents like party manifestos or platforms (Budge and Laver 1993; Petrocik 1996; Robertson 1976). However, our theory precisely focuses on the interelection period. This is why we rely on an emerging perspective on issue emphasis in parliamentary speaking (Chaqués-Bonafont, Palau, and Baumgartner 2014). Recent research compellingly shows that parliamentary questions and answers are a good proxy for party issue attention and are highly correlated with other communication sources like the media (Christiansen and Seeberg 2016). This suggests that parliamentary speaking is not simply a mechanical or strategic set of interactions different from messages targeted to public opinion.

While some work on parliamentary debates argues that the use of these speeches is less electoral and more policy related (Maltzman and Sigelman 1996), recent work on parliamentary settings has found that these strategic dynamics that were originally thought to be limited to campaigns also extend to the choices of issues by parties on the floor of parliaments (see, e.g., Martin and Vanberg 2008; Slapin and Proksch 2014; Van Aelst and Vliegenthart 2014; Vliegenthart and Walgrave 2011; Vliegenthart et al. 2016), even if these are constrained to the type of control that the party leadership can have on members of parliament (Slapin and Proksch 2014). However, our interest is more on the aggregate dynamics of party issue attention rather than the control over who speaks. In this sense, we follow the policy agenda-setting perspective that focuses on the overall priority of issues under discussion (GreenPedersen and Walgrave 2014).

Specifically, we are interested in the broad dynamics that make parties talk about the economy, which is a paradigmatic issue with important electoral consequences (Duch and Stevenson 2008; van der Brug, van der Eijk, and Franklin 2007). Two intuitive theoretical perspectives have suggested contradictory predictions: issue ownership and issue dialogue. Issue ownership theory has been used to understand both voting behavior and party strategy. In this article we are interested in the latter. Issue ownership theory argues that parties can effectively own issues for which they have a higher reputation and that parties have incentives to talk about those issues and not others (Bélanger and Meguid 2008; Petrocik 1996; Simon 2002).

As a performance issue, the economy relates directly to the incumbent government benefiting it in good times and being harmful in bad ones (Petrocik 1996; Vavreck 2009). Even if not contradictory with it, this departs from the interpretation of issue ownership as voters' perceptions of a party's reputa- 
tion or its capacity to handle a given issue, which is how voting behavior studies tends to view issue ownership. Some of these studies have shown that while perceptions of party competence exist, they can interact with the effects of performance (Bélanger and Nadeau 2014, 2015; Egan 2013). The literature using parties as units of analysis assumes a direct link between good macroeconomic conditions and positive perceptions of incumbent party competence among the public. On the basis of this conception of the economy as a performance issue and the fact that candidates still need to prime the economy for it to become salient (Austin 2013), we would expect that the incumbent will raise the issue in good economic times and ignore it when the economy is performing badly. In the latter scenario, the opposition party is instead the one that benefits from raising the issue (Vavreck 2009).

New research has challenged some of the strong assumptions underlying the models of issue competition described above (Williams, Seki, and Whitten 2015) and has focused on the degree to which parties speak on the same issues (Sigelman and Buell 2004). There are different theoretical reasons as to why issue dialogue would be expected. Among these, we find appearing responsive to the public, responding to a rival party, or following the media (see, e.g., Green-Pedersen and Mortensen 2014; Kaplan et al. 2006; Sagarzazu and Klüver 2017; Sigelman and Buell 2004; Simon 2002).

When parties follow the public to appear responsive, we say they "ride the wave" of public opinion (Ansolabehere and Iyengar 1994; Sides 2006; Sigelman and Buell 2004). In this model of dynamic agenda representation, if the priorities of the public change then the priorities of those in government should likewise change. If this happens, we should see a shift in the attention that politicians pay to different issues (Bevan and Jennings 2014). In this theoretical framework, the ultimate objective is to be seen as concerned, responsive, and informed (Ansolabehere and Iyengar 1994, 337). Recent research has found that parties do consider the public's preferences when drafting their election platforms (Spoon and Klüver 2015), in their press releases (Klüver and Sagarzazu 2016), and in their governing agendas (Green and Jennings 2017a). This shows that parties listen to citizens when developing their messaging. As the importance of economic issues increases for the electorate, so too should the attention that is paid to it by all parties.

Other research has argued that under certain circumstances parties will be pushed to respond to their rivals' discourse. This set of contributions finds evidence of candidates trespassing on issues where their ownership is weak (Arceneaux 2008), politicians obfuscating hurtful issues to lessen their impact (Alvarez 1997; Sides 2006), elected officials taking up opponents' campaign issues (Sulkin 2005), and candidates engaged in close races engaging in more dialogue (Kaplan et al. 2006). Alternatively, media and political science scholars have argued about the role that media plays in setting the agenda of political parties. While some have suggested that the media exerts a great deal of influence (Baumgartner, Jones, and Leech 1997; Chaqués-Bonafont and Baumgartner 2013; Soroka 2002), others find little to no impact (Wanta and Foote 1994). ${ }^{1}$

\section{THE CONDITIONING EFFECT OF THE ELECTORAL CYCLE Theoretical intuition}

In this section we develop a theoretical model incorporating the role of the electoral cycle explaining party issue attention. This model builds on issue ownership theory, which expects the electoral success of a given party to be a function of its competence on a given issue and the saliency of that issue in public opinion. We rely on this conventional model of electoral competition to derive our quantity of interest, namely, party attention on the economy, which will be our dependent variable in the analysis section.

Our main contribution is the parametrization of an electoral cycle component that strengthens the influence of competence and saliency as election day comes closer. The main assumption behind this model is that parties expect voters to be myopic and to take into account the most recent parties' performance when casting their ballots. Voter myopia has been a core assumption in many economic voting studies (Bartels 2008), even if it has also been suggested that voters are not myopic but rather misinformed (Hellwig and Marinova 2014). Regardless of whether voters are actually myopic, our assumption is that parties expect them to be so. In sum, we expect parties to believe that campaigns matter in informing and persuading voters (Gelman and King 1993; Popkin 1991).

In the context of competition between office-seeking parties who want to look particularly good at election time, parties are likely to perceive the consequences of not responding to an opponent's attack as particularly dangerous toward the end of the electoral cycle. Similarly, it is reasonable for parties to think that boosting their own reputation and framing competitors as incompetent can be particularly beneficial when voters are paying more attention to political issues and making up their minds before a vote. In other words, we expect office-seeking parties to believe that the risk of voters being persuaded of a bad performance and of the opponent increasing issue ownership can be more consequential close to an

1. For a comprehensive review, see Walgrave, Soroka, and Nuytemans (2008) and Walgrave and Van Aelst (2006). 
election (Williams 2013). The main result is thus that parties engage in dialogue more at the end of the cycle, when the marginal electoral gain or loss of controlling the agenda is greater. Subsequently, since the capacity of the agenda is limited, the attention to other factors like public opinion will necessarily decrease once parties engage in direct dialogue.

\section{Assumptions}

Suppose there are two political parties, 1 (in opposition) and 2 (in government), and that there are two issues, $a$ (i.e., the economy) and $b$ (i.e., a noneconomic issue), that might influence voters' choices. We assume that the payoff of party $i$ is determined by its expected vote share, $v_{i}$, which for each $i$, $j \in\{1,2\}$ with $j \neq i$ is given by

$$
v_{i}=s^{a} p_{i}^{a}\left(x_{i}^{a}, x_{j}^{a}\right)+s^{b} p_{i}^{b}\left(x_{i}^{b}, x_{j}^{b}\right)
$$

where for each $k \in\{a, b\}, p_{i}^{k}$ is a Tullock function (Corchón 2007; Tullock 1980) of the form

$p_{i}^{k}\left(x_{i}^{k}, x_{j}^{k}\right)=\left\{\begin{array}{cl}\frac{\left(c_{i}^{k} x_{i}^{k}\right)^{e}}{\left(c_{i}^{k} x_{i}^{k}\right)^{e}+\left(c_{j}^{k} x_{j}^{k}\right)^{e}} & \text { if } x_{i}^{k}>0 \text { and } x_{i}^{k}>0 \\ \frac{1}{2} & \text { otherwise }\end{array}\right.$.

Vote shares are determined as follows: $s^{a}$ and $s^{b}$ denote the salience of issues $a$ and $b$ in public opinion, respectively. We assume that $s^{a}+s^{b}=1$, so the salience of an issue can be interpreted as the probability with which a voter will vote on the basis of that issue. We denote the electoral return of party $i$ on issue $k \in\{a, b\}$ by $p_{i}^{k}\left(x_{i}^{k}, x_{j}^{k}\right)$. Since $p_{i}^{k}\left(x_{i}^{k}, x_{j}^{k}\right)+$ $p_{j}^{k}\left(x_{j}^{k}, x_{i}^{k}\right)=1$, the electoral return of party $i$ on issue $k$ can be interpreted as the probability that a voter will vote for party $i$ conditional on voting on the basis of issue $k$. So $v_{i}$ is indeed the expected vote share for party $i$.

The electoral return of party $i$ on issue $k$ is determined by $x_{i}^{k}$ and $x_{j}^{k}$, which denote the degree to which parties $i$ and $j$ highlight issue $k$, respectively. For party $i, x_{i}^{k}$ can, for example, be interpreted as the fraction of time devoted to discussing issue $k$ in parliamentary discussions. So for each party $i$, we assume that $x_{i}^{a}+x_{i}^{b}=1$. That is, when there are only two issues, whatever fraction of time is not devoted to discussing issue $a$ is devoted to discussing issue $b$. Furthermore, the electoral return of party $i$ on issue $k$ is also parametrized by $c_{i}^{k}$ and $c_{j}^{k}$, which denote the competence of parties $i$ and $j$ on issue $k$. With only two parties, we assume for simplicity that $c_{i}^{k}+c_{j}^{k}=1$, so $c_{i}^{k}$ is in fact the relative competence of party $i$ on issue $k$, with $c_{i}^{k}>1 / 2$ indicating that party $i$ is relatively more competent on issue $k$ than party $j$ and vice versa. Competence here does not refer to public perceptions of competence, which could be endogenous to party preference, but to some form of economic competence exog- enous to partisan biases (i.e., objective macroeconomic fluctuations). It is also reasonable to expect that parties focus on hard economic indicators to infer their own credibility on the issue of the economy. Finally, the electoral return of party $i$ on issue $k$ also depends on $e \in[0,1]$, which captures how distant one is (in time) from the electoral cycle. For the sake of simplicity in this model, we assume that the electoral cycle variable can only have two values (far from election time, and close to the next election). The empirical analysis, however, will test our expectations using a more realistic continuous measure of time.

To give a sense of how the value of this electoral return function varies with its parameters, consider the extreme case in which $e=0$. Then, regardless of how much parties choose to highlight issue $k$, and regardless of their relative competence on issue $k$, the electoral return of each party is $1 / 2$. But, as $e$ increases (closer to election time), the issue highlighting choices and the relative competences of the parties start to matter in determining parties' electoral returns. The parameter $e$ thus captures the intuition that voters are probably myopic and that their voting choices are more likely to be influenced by the parties' strategies closer to election time. Finally, note that for any $e>0$, the electoral return of party $i$ on issue $k$ is increasing in the degree to which $i$ chooses to highlight issue $k$ and is increasing in $i$ 's competence on issue $k$, but the effect of increasing the degree to which $i$ chooses to highlight issue $k$ when i's competence on issue $k$ is low is smaller than if $i$ s competence on issue $k$ were high. ${ }^{2}$ Finally, note that if both parties choose to not highlight issue $k$ at all (so $x_{i}^{k}=x_{j}^{k}=0$ ), then the electoral return of any party on this issue is $1 / 2$. While the results of the model are particularly sensitive to this assumption, we believe it is a reasonable one. If parties decide not to talk at all about any issue, the result of the election will be based on non-issue-based calculations like partisanship or the mobilization of its own social constituency. Assuming that parties 1 and 2 are equally mainstream and with comparable partisan and social bases in the party system, we assume that avoiding issue-based competition will benefit parties half of the time.

\section{The model}

Given our assumptions above, we can simplify the notation by letting $s=s^{a}$ (so $1-s=s^{b}$ ). Similarly, let $x_{i}=x_{i}^{a}$ and suppose $x_{i} \in\{0,1\}$ for $i \in\{1,2\}$, and let $c^{k}=c_{2}^{k}$ for

2. For example, a given party may have been seen to be incompetent on certain issues (say, foreign relations), but its power to attract voters on that issue was arguably increasing in its number of media appearances. And had it been perceived as being competent, its power to attract would have been even higher had it done the same number of media appearances. 
A
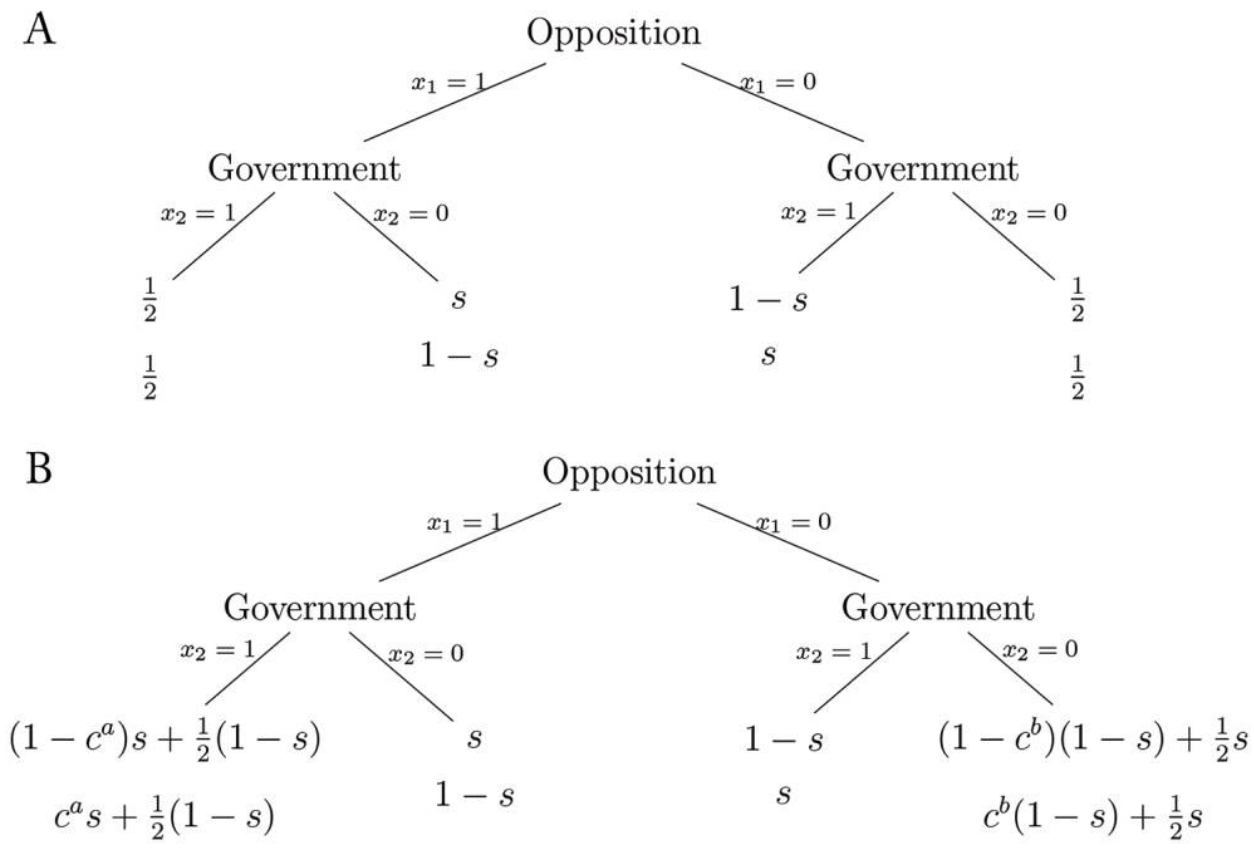

Figure 1. Extensive form representation of the game for $e=0(A)$ and $e=1(B)$

$k \in\{a, b\}$ (so that $c^{k}$ represents the relative competence of the government party on issue $k$ ), and finally suppose that $e \in\{0,1\}$.

Suppose that the game is sequential: the opposition party chooses $x_{1}$, and the incumbent observes the opposition's choice and subsequently chooses $x_{2}$. When modeling a parliamentary exchange, it is reasonable to expect an iterative dialogue in which the two main parties do not speak at the same time. The idea of a sequential game in which the opposition tends to open question-and-answer time and is less constrained by real world events is compatible with extant empirical research on government opposition dynamics (PardosPrado and Sagarzazu 2016; Seeberg 2013). The game tree is represented in figure 1 , and the payoffs in figures $1 A$ and $1 B$ are obtained by substituting for the appropriate values in equations (1) and (2).

\section{Propositions}

We are now able to characterize the subgame perfect equilibriums of this game. We say that the government party (party 2) has high effective competence relative to the opposition party (party 1 ) on issue $a$ if

$$
c^{a} \geq \frac{1}{2} \frac{1-s}{s},
$$

and we say that the government party has high effective competence relative to the opposition party on issue $b$ if

$$
c^{b} \geq \frac{1}{2} \frac{s}{1-s} .
$$

Proposition 1. When $e=0$, the parties highlight the issue that is most salient in public opinion. ${ }^{3}$ And, when $e=1$,

1. If the government party has high effective competence on all issues, then that party chooses to highlight whichever issue the opposition chooses to highlight, and the opposition chooses to highlight the issue for which the government has a relatively lower effective competence. ${ }^{4}$

2. If the government party has high effective competence on one issue but not the other, then it chooses to highlight the issue that the party is most effectively competent at, and the opposition party chooses to highlight the most salient issue in public opinion.

3. If the government has low effective competence on all issues, then the government chooses to highlight whichever issue the opposition does not highlight, and the opposition chooses to highlight the most salient issue.

The novel contribution of our model lies in proposition 1.1, which will be the main object of our empirical analysis. The remarkable aspect of this proposition is that

3. Suppose that if $s>1 / 2$, party 2 chooses $x_{2}=1$ regardless of what party 1 does, and party 1 chooses $x_{1}=1$.

4. The incumbent has a relatively high effective competence on issue $b$ whenever $c^{b} \geq(1 / 2)[(1-2 s) /(1-s)]+[s /(1-s)] c^{a}$. 
A

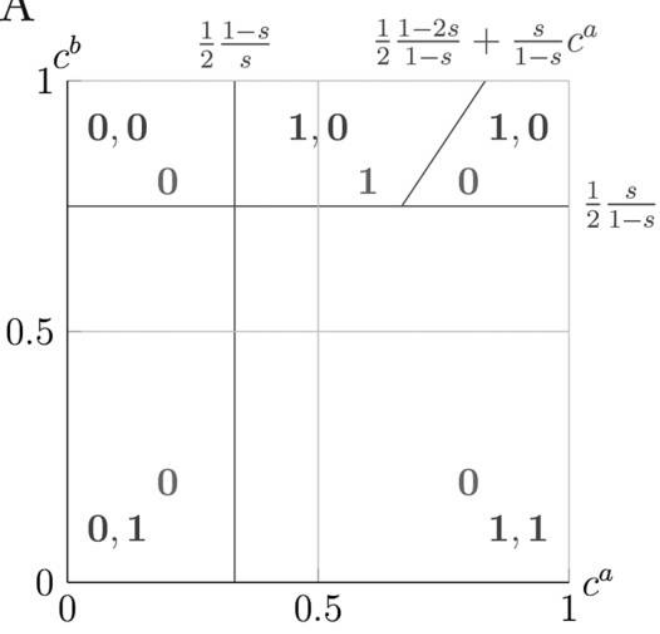

B

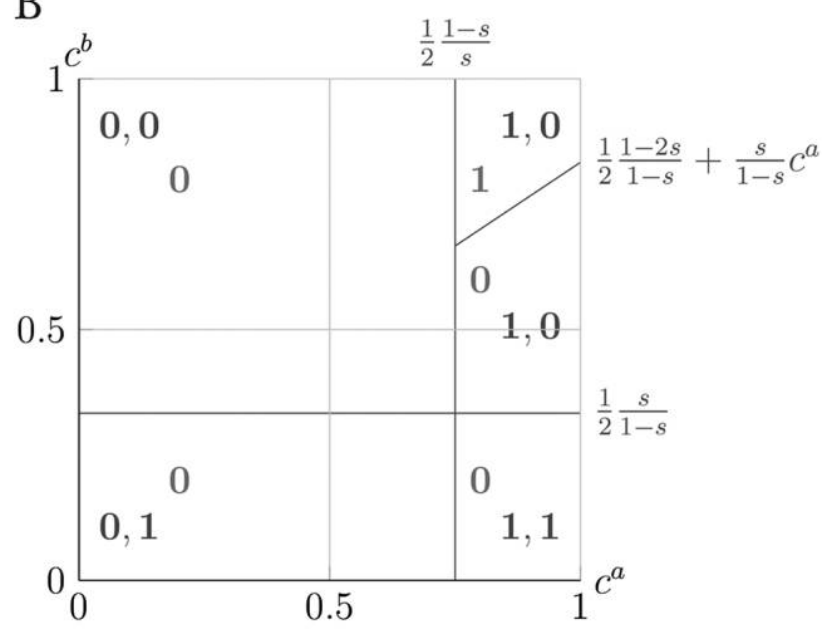

Figure 2. Characterization of the equilibriums of the game for $e=1$. A, Game when $s>1 / 2$. B, Game when $s<1 / 2$

if the government party has high effective competence on all issues, then both the opposition and the incumbent party choose to highlight the same issue regardless of its salience in public opinion. That is, public opinion is essentially ignored as the electoral cycle goes by. When $e=0$, the comparisons are trivial since parties will tend to highlight the issue that is more salient in the public. The results stated in the above proposition for $e=1$ are shown in figure 2 . We represent the choices of the government in paired numbered plots, with say 0,1 indicating that the incumbent chooses to not highlight issue $a$ if the opposition does but to highlight issue $a$ if the opposition does not. The choices of the opposition are represented in the innermost single-numbered plots. For example, in figure $2 A$, the top-right corner is the one in which the government has high effective competence over both issues. However, that area is segmented by a diagonal line into two areas, with the one on the left representing the area in which the government is relatively less effectively competent in issue $a$. In that area, we have that the government party chooses to highlight issue $a$ if the opposition highlights issue $a$, and the government chooses to highlight issue $b$ if the opposition chooses to highlight issue $b$ (indeed the choice of the incumbent in that area is given by 1,0 ). Furthermore, in that area, the opposition chooses to highlight issue $a$ (represented by the 1), which is the issue at which the government is relatively less effectively competent. A similar situation arises in the top-right corner of figure $2 B$, which thus shows that the choice of issue to highlight does not depend on the salience of the issue in public opinion.

\section{RESEARCH DESIGN}

\section{Spain: A bipartisan multiparty system}

We test our argument by using data from Spain. Although Spain has a multiparty system, it has functioned with a bipartisan government dynamic until recently, where two major parties have alternated power in single-party governments. Even if the relative majorities of the governing parties and the need for agreements with a third (mainly nationalist) party have varied, the relatively small district magnitude and high concentration of executive power in the Spanish political system explain the prominence of the two main central parties. The electoral system is a standard proportional closed-party list where members of parliament have very little autonomy and incentives to challenge the party elite on the floor. This case study is thus particularly suited to the assumptions underpinning our model: two main competing and office-seeking parties relatively free from intraparty politics and coalition compromises. This is not to say that Spain is a unique case, however. Spain is a proportional multiparty parliamentary democracy with a pattern of government alternation and parliamentary structure highly comparable to other Western democracies. In fact, the Spanish case provides a particularly good compromise between our model assumptions and a reasonable level of external validity.

The time span of our analysis, from 1996 to 2011, covers these dynamics by including four governments, two led by the right-wing Partido Popular (PP) and the other two led by the left-wing Partido Socialista Obrero Español (PSOE). ${ }^{5}$ Furthermore, these four periods include varying macroeconomic conditions that span relative economic strength to being one of the hardest hit democracies during the global economic meltdown that started at the end of last decade.

\section{Party questioning of government}

Party issue attention is our dependent variable and refers to $x_{i}^{k}$ and $x_{j}^{k}$ in our model. ${ }^{6}$ In order to measure issue attention

5. During these four periods both PP and PSOE were able to govern without the need of any coalition partner.

6. Table 7 in app. 4 (apps. 1-4 are available online) shows descriptive statistics of all our dependent and independent variables. 
Table 1. Average Number of Questions Asked in Plenary Sessions and Total per Legislature

\begin{tabular}{|c|c|c|c|c|c|c|c|}
\hline \multirow[b]{2}{*}{ Legislature } & \multirow[b]{2}{*}{ No. Plenary Sessions } & \multicolumn{2}{|c|}{ PP } & \multicolumn{2}{|c|}{ PSOE } & \multicolumn{2}{|c|}{ Others } \\
\hline & & Average & Total & Average & Total & Average & Total \\
\hline $6(1996-2000)$ & 72 & 9 & 612 & 9 & 638 & 4 & 277 \\
\hline 7 (2000-2004) & 66 & 10 & 800 & 8 & 660 & 4 & 342 \\
\hline $8(2004-2008)$ & 56 & 8 & 683 & 8 & 680 & 6 & 437 \\
\hline $9(2008-2011)$ & 9 & 9 & 260 & 4 & 112 & 4 & 108 \\
\hline
\end{tabular}

Note. $\mathrm{PP}=$ Partido Popular; PSOE $=$ Partido Socialista Obrero Español.

by the two major Spanish parties, we rely on the questions made by party members in the plenary sessions of the Spanish Parliament and aggregate our measures at the month level (like the rest of our variables). As discussed above, parliamentary appearances have been proved to correlate highly with party messages from external sources of communication like the media (Christiansen and Seeberg 2016). In most plenary sessions (plenos in Spanish), there is a section where different members of parliament can question the government representatives who are present. Exchanges between legislators in plenary sessions have been used frequently in political science literature; uses range from ideological position estimates to understanding a given party's attention to specific issues (see, e.g., Green-Pedersen and Mortensen 2010; Klüver and Sagarzazu 2016; Pardos-Prado and Sagarzazu 2016; Sagarzazu and Klüver 2017; Slapin and Proksch 2014; Vliegenthart and Walgrave 2011).

Publicly available plenary debates data were obtained from the Spanish Parliament. We restrict our sample to the data points with valid observations in all our independent variables. Table 1 shows the total number of plenary sessions in which questions were asked in our sample. It also shows the average number of questions asked in each session by each of the two main parties and the total number of questions asked per legislature, by party.

The data show that the parliamentary debate is dominated by the two largest parties, the PP and the PSOE. On average, both parties have a similar number of interactions per plenary, regardless of their role as government or opposition. The last legislature (2008-11) when the PSOE was in power saw a big drop in the number of sessions with questions and in the number of questions (especially by the PSOE). This behavior is consistent with the mechanisms of agenda control implemented by the PSOE to minimize its exposure due to the financial crisis. It is important to note, however, that this circumstance should go against our claim that government and opposition can ultimately engage in dialogue rather than in selective issue emphasis. Moreover, the analyses below show that the last electoral cycle has not biased our findings in any way. We use parliamentary questions as the input data for the quantitative text analysis algorithm. The output of this process measures attention by the different parties to seven different issues, of which we will solely focus on the economy. Using this mechanism, we classify each word as pertaining to the economy (1) or not (0) and aggregate words for parties at the monthly level. As not all parties are allotted equal time, we generate comparable measures by dividing the number of words on the economy over the total number of words in the month. As such our dependent variable is the percentage of words on the economy by a party in a given month.

In order to illustrate how issue attention varied over the course of the four legislative terms, figure 3 plots the attention that the PSOE and the PP paid to the economy as a proportion of the total time the party spoke. This figure shows two interesting dynamics that occur in the four legislatures. First, a similar attention dynamic can be found in the sixth and eighth legislatures (legislative sessions are identified in roman numerals), in which we see no major differences between the parties. These legislatures are similar not only in the attention paid to the economy by both parties but also in the fact that they were the result of a change in control of parliament and ended in a reelection of the governing party. The second dynamic can be seen in the other two legislatures plots in figure 3 in which we see more attention paid to the economy by the opposition party (i.e., PSOE in the seventh legislature and PP ninth legislature). While the dominance of the PSOE is clearer in the seventh legislature than the PP's dominance in the ninth legislature, the overall pattern is present throughout.

\section{Independent variables}

To test the theories explained in the previous section, we collected data on the economy, public opinion, and the media.

7. For details on the process of converting questions to valid measures of attention, see app. 1 


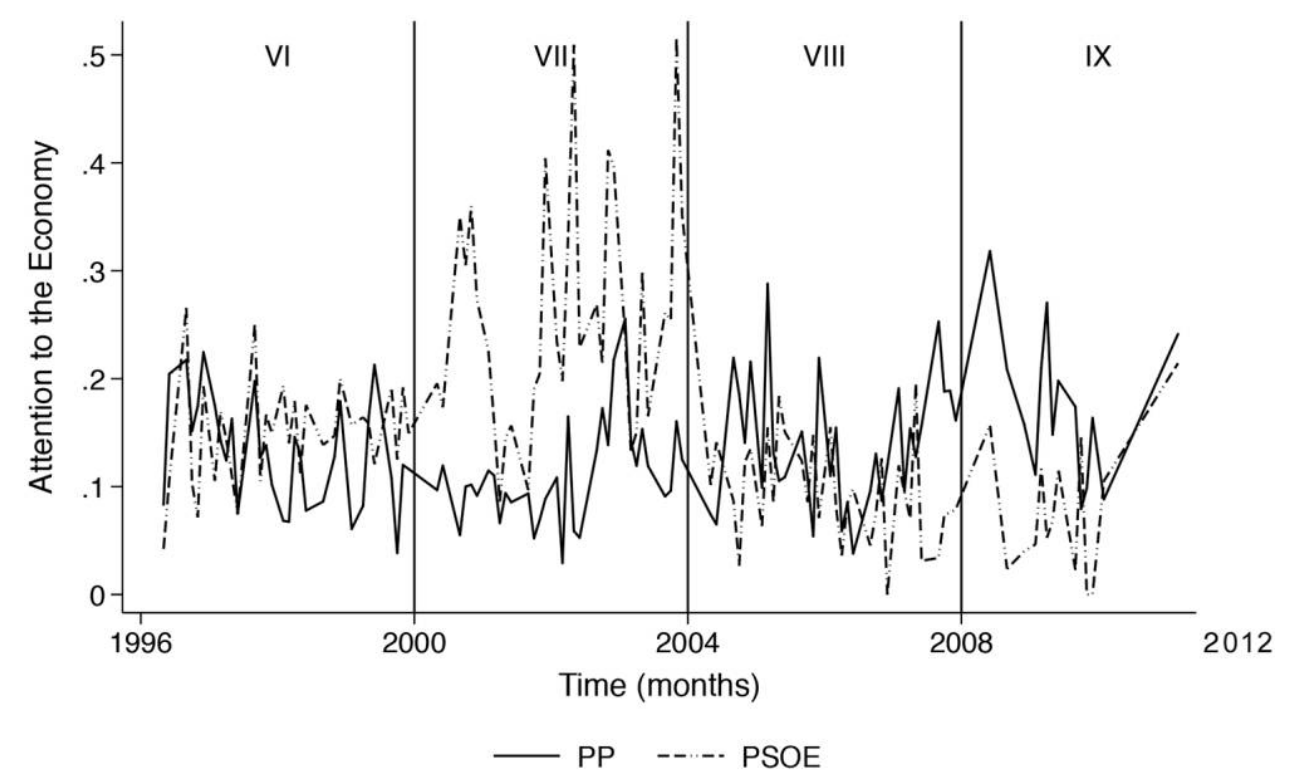

Figure 3. Issue attention over time. PP = Partido Popular; PSOE = Partido Socialista Obrero Español

Economy. Macroeconomic competence and performance refers to $c_{i}^{k}$ and $c_{j}^{k}$ in our model. We rely on the tradition of issue ownership studies analyzing party emphasis as units of analysis, in which economic reputation is directly inferred from macroeconomic conditions (Vavreck 2007). Even if perceptions of party competence are partly driven by economic shocks (Green and Jennings 2017b), this does not mean that we assume macroeconomic conditions to perfectly reflect voter perceptions. Since our focus is party strategy, however, it is reasonable to expect parties to use fluctuations in the real economy as a heuristic to infer their reputation and not use aggregate measures of party competence that are scarcely available in Spanish public opinion surveys. Economic data were obtained from the Instituto Nacional de Estadistica data sets (http:// www.ine.es/); specifically, we use the indicators for monthly unemployment and gross domestic product (GDP) growth. ${ }^{8}$

Public opinion. Public opinion refers to $s^{a}$ in our model. Public opinion data were obtained from monthly surveys conducted by the Centro de Investigaciones Sociologicas (CIS) in Spain. The CIS conducts monthly public opinion polls together with many other types of surveys in Spain. ${ }^{9}$ Each of the monthly

8. GDP data are only collected every three months, but we have imputed missing values with unemployment, inflation, party and media attention, economic perceptions, and time trends using multiple imputation procedures in Stata 14 (setting the random seed generator number to 100). Tables 13 and 14 in app. 3 show how the results in the following section do not substantially change if GDP growth is excluded from the analyses.

9. Technical documentation and sampling procedures of each survey can be found at http://www.cis.es. barometers contains a random sample of the Spanish population with valid answers to our dependent variable (sample size varies between 2,376 and 4,874 individuals).

To measure the degree of public attention to the economy, we used the most important problem (MIP) question. Specifically, we use the share of respondents concerned about the economy as a proxy for public opinion saliency of this topic. As highlighted in previous work, MIP measures might reflect not only salience but also considerations of the economy as a problem. Both interpretations of MIP questions would be consistent with the mechanisms we intend to test (i.e., whether parties respond to public attention, salience, or concern over the economy). While we recognize the attention scholars are raising to the difference between the MIP and the most important issue (Wlezien 2005), it is also true that these measures "mostly tap the same things" (Jennings and Wlezien 2011, 554).

In order to strengthen our MIP measure as the potential effect of saliency net of other problem-based views on the economy, we control for the current and lagged assessment of the national state of the economy. The wording of the question is "With regards to the general economic situation in Spain, how would you assess it?" The possible answers are "very good," "good," "neither good nor bad," "bad," and "very bad." 10

10. This variable has a moderately high correlation with the retrospective economic evaluations question, which was asked in only 58 surveys $(r=.42$, $p=.000)$. Furthermore, when running a factor and a principal components analysis, both items clearly load on the same dimension, with factor loadings of 0.54 and 0.71 , respectively. 
Media. The media is another actor to consider as a source of agenda-setting capabilities. While some have suggested that the media exerts a great deal of influence (Baumgartner et al. 1997; Chaqués-Bonafont and Baumgartner 2013; Soroka 2002; Van Aelst and Vliegenthart 2014; Vliegenthart and Walgrave 2011), others find little to no impact (Wanta and Foote 1994) or that influence is conditioned by system characteristics (Vliegenthart et al. 2016). ${ }^{11}$ Data on media attention were obtained from the Policy Agendas Project (Chaqués-Bonafont et al. 2014), which coded the front page of the two most important Spanish newspapers El Mundo and El Pais for the presence of stories on 21 topic areas. As our interest is stories about the economy, we aggregated their data and estimated the proportion of news stories on the economy over the total number of stories for each month in the data set. The result of this aggregation is a time series of overall coverage on the economy by the two main Spanish newspapers.

Modeling strategy. Our modeling strategy relies on both parametric and semiparametric time series analyses. For the parametric analyses, we model our expectations with autoregressive distributed lag (ADL) models. The advantage of this conventional modeling strategy (which is mathematically equivalent to error correction models; De Boef and Keele 2008) is that we can estimate both the short-term and longterm effects of our covariates of interest. Given our theoretical focus on the electoral cycle, we prefer to be agnostic about the possible effects of our potential confounders over time. This is why, following previous research, we chose a conservative and unrestricted version of ADL models including the contemporaneous and lagged versions of our independent variables. Our interactions with electoral cycle are measured at $t-1$, to strengthen the plausibility of a causal effect whereby parties' reactions are a function of recent stimuli. Table 21 in appendix 3, however, shows that our conclusions remain unchanged if the interactions are specified with the electoral cycle measured at time $t^{12}$

Moreover, our general ADL specification allows us to include the lagged value of our dependent variable and a time trend, which are both strong controls to reduce biases linked

11. For a comprehensive review, see Walgrave and Van Aelst (2006) and Walgrave et al. (2008).

12. Figure 1 in app. 2 reports the autocorrelation and partial autocorrelation functions of our dependent variables of interest (government and opposition issue attention). These suggest an autoregressive process with one lag- $\mathrm{AR}(1)$ - for both variables. Tables 5 and 6 in app. 2 further report satisfactory Portmanteau tests concerning the residuals of the models shown in the next section. In all those models, we can never reject the null hypothesis that the $(1,2,3, \ldots t)$ lagged residuals are part of a white noise process. Given these tests, we did not see the need to include further lags beyond $t-1$ to serial correlation or unobserved time-dependent variables. It is important to note, however, that our results remained unchanged if we do not specify a lagged dependent variable and a time trend. This reassured us that introducing these strong controls did not introduce bias into the models.

\section{RESULTS}

Table 2 reports two ADL models predicting government and opposition party attention to the issue of the economy, respectively. More specifically, these models present the direct effects of the rival party's attention, macroeconomic fluctuations (unemployment and GDP growth), the share of people mentioning the economy as the MIP, the average level of national economic evaluations, and media attention to the economy.

The first model in table 2 suggests that the average effects of the main opposition party, the media, and aggregate public concern and dissatisfaction with the economy are not significant drivers of government's attention to the economy. Only the lagged effect of GDP growth has a highly significant effect at conventional levels. When calculating the long-term effect of GDP growth on government's attention, $\left(\beta_{1}+\beta_{2}\right) /$ $\left(1-\beta_{0}\right)$, it appears to be very small $(b=.0001)$ but significant according to a Wald test $(p=.03)$. This finding confirms an intuitive expectation of issue ownership theory, which was also contained in proposition 1.2 in the theoretical model above: when the economy grows, incumbents feel that their economic credibility increases and subsequently tend to focus more on the economy.

The final column in table 2 replicates the same ADL model but with opposition party attention to the economy as the dependent variable. In this case, the effect of contemporaneous media attention is very strong and statistically significant. This suggests that the media and the opposition tend to highlight economic issues at the same time. If one assumes that parties see the media as an amplifier of public opinion concerns, this result is consistent with the predictions of our model. Even if the analysis of media attention is out of the scope of our article, table 8 in appendix 3 explores this relationship further by replicating the same model using media attention as the dependent variable. In that model, negative public economic perceptions are the only significant driver of media attention $(b=.03)$. We have then further explored this indirect sequence by fitting a model with negative economic perceptions as the dependent variable, also in table 8 in appendix 3. Intuitively, the short-term effect of GDP growth $(b=-.0001)$ and the short term $(b=.12)$ and long-term $(b=.02)$ effects of unemployment appear to be the strongest drivers of public evaluations of the national economy. The interpretation of these findings is an indirect effect of mac- 
Table 2. Autoregressive Distributed Lag Models Predicting Government and Opposition Economic Attention without Electoral Cycle Interactions

\begin{tabular}{|c|c|c|}
\hline & $\begin{array}{c}\text { Government } \\
\text { Attention }_{t}\end{array}$ & $\begin{array}{c}\text { Opposition } \\
\text { Attention }_{t}\end{array}$ \\
\hline Government attention $_{t}$ & $\begin{array}{l}\ldots \\
\ldots\end{array}$ & $\begin{array}{r}.250 \\
(.20)\end{array}$ \\
\hline Government attention $_{t-1}$ & $\begin{array}{l}.148 \\
(.10)\end{array}$ & $\begin{array}{r}-.080 \\
(.19)\end{array}$ \\
\hline Opposition attention $_{t}$ & $\begin{array}{l}.072 \\
(.06)\end{array}$ & $\begin{array}{l}\cdots \\
\cdots\end{array}$ \\
\hline Opposition attention $_{t-1}$ & $\begin{array}{c}.009 \\
(.06)\end{array}$ & $\begin{array}{l}.376^{* * *} \\
(.11)\end{array}$ \\
\hline $\mathrm{MIP}_{t}$ & $\begin{array}{c}.082 \\
(.17)\end{array}$ & $\begin{array}{r}-.286 \\
(.31)\end{array}$ \\
\hline $\mathrm{MIP}_{t-1}$ & $\begin{array}{r}.130 \\
(.17)\end{array}$ & $\begin{array}{c}.185 \\
(.32)\end{array}$ \\
\hline Unemployment $_{t}$ & $\begin{array}{l}.004 \\
(.02)\end{array}$ & $\begin{array}{l}.033 \\
(.03)\end{array}$ \\
\hline Unemployment $_{t-1}$ & $\begin{array}{r}-.002 \\
(.02)\end{array}$ & $\begin{array}{r}-.041 \\
(.03)\end{array}$ \\
\hline GDP growth & $\begin{array}{c}2 \mathrm{E}-05 \\
(3 \mathrm{E}-05)\end{array}$ & $\begin{array}{r}-5 \mathrm{E}-05 \\
(5 \mathrm{E}-05)\end{array}$ \\
\hline GDP growth $_{t-1}$ & $\begin{array}{l}.0001^{\star \star \star} \\
(3 \mathrm{E}-05)\end{array}$ & $\begin{array}{c}7 \mathrm{E}-06 \\
(6 \mathrm{E}-05)\end{array}$ \\
\hline Economic perceptions $_{t}$ & $\begin{array}{r}-.062 \\
(.06)\end{array}$ & $\begin{array}{c}-.084 \\
(.10)\end{array}$ \\
\hline Economic perceptions $_{t-1}$ & $\begin{array}{l}.096^{*} \\
(.05)\end{array}$ & $\begin{array}{l}.007 \\
(.10)\end{array}$ \\
\hline Media attention $_{t}$ & $\begin{array}{r}-.217 \\
(.39)\end{array}$ & $\begin{array}{l}1.410^{\star *} \\
(.70)\end{array}$ \\
\hline Media attention ${ }_{t-1}$ & $\begin{array}{l}.147 \\
(.39)\end{array}$ & $\begin{array}{r}-.538 \\
(.73)\end{array}$ \\
\hline Time trend & $\begin{array}{r}-.001 \\
(.00)\end{array}$ & $\begin{array}{r}-.001 \\
(.00)\end{array}$ \\
\hline Constant & $\begin{array}{r}-.027 \\
(.11)\end{array}$ & $\begin{array}{l}.428^{\star *} \\
(.21)\end{array}$ \\
\hline$F$ & 3 & 2 \\
\hline$R^{2}$ & .299 & .294 \\
\hline Log likelihood & 171.763 & 110.856 \\
\hline BIC & -274.751 & -152.937 \\
\hline
\end{tabular}

Note. Standard errors in parentheses. MIP = most important problem; $\mathrm{GDP}=$ gross domestic product; $\mathrm{BIC}=$ Bayesian information criterion . $N=98$.

$* p<.1$.

${ }^{* *} p<.05$.

${ }^{* * *} p<.01$.

roeconomic conditions, consistent with issue ownership theory: unemployment and GDP downturns increase negative evaluations of the economy and media attention, which subsequently increases the opposition attention to the economy as well.
Table 3 reports a set of fully specified ADL models testing the role of the electoral cycle (measured in months, with higher values representing more proximity to the next election), which is our main contribution. Models 1 and 2 analyze government attention as the dependent variable and test the interaction of the electoral cycle with opposition attention and MIP, respectively. Models 3 and 4 replicate the same specification but with opposition attention as the dependent variable. If the main theoretical proposition sketched out above is valid, the pressure exerted by proximity to election day should increase the incentives of the incumbent to dispute and respond to the opposition's attacks in order to avoid losing credibility. As shown in model 1 in table 3, this is indeed the case. The interaction between lagged opposition party attention to the economy and the electoral cycle is positive and significant. All the constitutive and multiplicative terms of the interaction are strongly significant, and the sign of the multiplicative term suggests that the tendency of the government party to respond to opposition messages increases as election day approaches. But, the interaction with the lagged effect of public concern over the economy (model 2) has a weaker effect as the electoral cycle progresses. ${ }^{13}$ These findings are entirely consistent with proposition 1 above, which predicted that under the assumption of comparable competence across issues, the incumbent chooses to highlight whichever issue the opposition highlights but only at the end of the cycle. Our proposition also expected the incumbent to be more responsive to saliency in public opinion early in the cycle. ${ }^{14}$

Table 3 furthermore tests whether the electoral cycle conditions the strategy of opposition parties (models 3 and 4). In this case, none of the interaction terms are significant. ${ }^{15}$ The clearest finding regarding the opposition communication strategy is thus the mediated effect of unemployment increasing the opposition's attention to the economy via negative economic evaluations and the media. This finding is in line with issue ownership theories expecting opposition parties to focus on economic issues when the economy performs poorly and at any given time during the electoral cycle. This is also consistent with our theoretical model above, which expected

13. Tables 11 and 12 in app. 3 show the effect of the interactions between the electoral cycle and macroeconomic indicators and the media. All results are insignificant, indicating that, as predicted, the electoral cycle mainly conditions the effect of opposition attention and MIP.

14. Tables 19 and 20 in app. 3 show that our key results in tables 2 and 3 are consistent when controlling for the total attention devoted to the economy by all parties with parliamentary representation.

15. Table 21 in app. 3 shows that our main conclusions are not sensitive to the specification of the electoral cycle as a contemporaneous or lagged predictor in the interaction terms. We opted to report the lagged interactions in the main text, since they are more intuitive from a Granger causality point of view. 
Table 3. Autoregressive Distributed Lag Models Predicting Government and Opposition Economic Attention with Electoral Cycle Interactions

\begin{tabular}{|c|c|c|c|c|}
\hline & \multicolumn{2}{|c|}{ Government Attention $_{t}$} & \multicolumn{2}{|c|}{ Opposition Attention $_{t}$} \\
\hline & Model 1 & Model 2 & Model 3 & Model 4 \\
\hline \multirow[t]{2}{*}{ Government attention $_{t}$} & $\ldots$ & $\ldots$ & .2392 & .2511 \\
\hline & $\ldots$ & $\ldots$ & $(.204)$ & $(.210)$ \\
\hline \multirow[t]{2}{*}{ Government attention $_{t-1}$} & .0961 & .1253 & .0659 & -.0746 \\
\hline & $(.100)$ & $(.102)$ & $(.455)$ & $(.196)$ \\
\hline \multirow[t]{2}{*}{ Opposition attention $_{t}$} & .0570 & .0693 & $\ldots$ & $\ldots$ \\
\hline & $(.056)$ & $(.058)$ & $\ldots$ & $\ldots$ \\
\hline \multirow[t]{2}{*}{ Opposition attention $_{t-1}$} & $-.3015^{* * *}$ & .0306 & $.3604^{* * *}$ & $.3562^{* * *}$ \\
\hline & $(.114)$ & $(.061)$ & $(.107)$ & $(.110)$ \\
\hline \multirow[t]{2}{*}{$\mathrm{MIP}_{t}$} & .0661 & .1792 & -.3452 & -.3417 \\
\hline & $(.162)$ & $(.174)$ & $(.328)$ & $(.330)$ \\
\hline \multirow[t]{2}{*}{$\mathrm{MIP}_{t-1}$} & .0811 & $.7257^{\star *}$ & .1423 & -.0156 \\
\hline & $(.166)$ & $(.330)$ & $(.326)$ & $(.646)$ \\
\hline \multirow[t]{2}{*}{ Electoral cycle ${ }_{t-1}$} & $-.0032^{\star *}$ & $.0015^{*}$ & .0019 & .0007 \\
\hline & $(.001)$ & $(.001)$ & $(.003)$ & $(.002)$ \\
\hline \multirow[t]{2}{*}{ Government attention $_{t-1} \times$ electoral $_{\text {cycle }} t-1$} & $\ldots$ & $\ldots$ & -.0078 & $\ldots$ \\
\hline & $\ldots$ & $\ldots$ & $(.022)$ & $\ldots$ \\
\hline \multirow[t]{2}{*}{ Opposition attention $_{t-1} \times$ electoral cycle $_{t-1}$} & $.0178^{\star * *}$ & $\ldots$ & $\ldots$ & $\ldots$ \\
\hline & $(.006)$ & $\ldots$ & $\ldots$ & $\ldots$ \\
\hline \multirow[t]{2}{*}{$\mathrm{MIP}_{t-1} \times$ electoral cycle $e_{t-1}$} & $\ldots$ & $-.0277^{\star \star}$ & $\ldots$ & .0073 \\
\hline & $\ldots$ & $(.013)$ & $\ldots$ & $(.025)$ \\
\hline \multirow[t]{2}{*}{ Unemployment $_{t}$} & .0073 & .0069 & .0319 & .0272 \\
\hline & $(.017)$ & $(.018)$ & $(.035)$ & $(.033)$ \\
\hline \multirow[t]{2}{*}{ Unemployment $_{t-1}$} & -.0122 & -.0078 & -.0419 & -.0372 \\
\hline & $(.018)$ & $(.018)$ & $(.035)$ & $(.034)$ \\
\hline \multirow{2}{*}{ GDP growth g $_{t}$} & $1 \mathrm{E}-05$ & $1 \mathrm{E}-05$ & $-4 \mathrm{E}-05$ & $-5 \mathrm{E}-05$ \\
\hline & $(2 \mathrm{E}-05)$ & $(2 \mathrm{E}-05)$ & $(5 \mathrm{E}-05)$ & $(5 \mathrm{E}-05)$ \\
\hline \multirow[t]{2}{*}{ 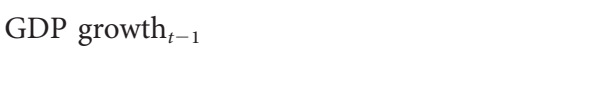 } & $8 \mathrm{E}-05^{\star * *}$ & $8 \mathrm{E}-05^{\star * *}$ & $1 \mathrm{E}-05^{\star * *}$ & $1 \mathrm{E}-05^{\star * *}$ \\
\hline & $(2 \mathrm{E}-05)$ & $(2 \mathrm{E}-05)$ & $(5 \mathrm{E}-05)$ & $(5 \mathrm{E}-05)$ \\
\hline \multirow[t]{2}{*}{ Economic perceptions $_{t}$} & -.0351 & -.0416 & -.0741 & -.0717 \\
\hline & $(.054)$ & $(.056)$ & $(.107)$ & $(.107)$ \\
\hline \multirow[t]{2}{*}{ Economic perceptions $_{t-1}$} & $.1352^{\star \star}$ & $.0972^{\star}$ & .0141 & .0213 \\
\hline & $(.052)$ & $(.052)$ & $(.103)$ & $(.101)$ \\
\hline \multirow[t]{2}{*}{ Media attention $_{t}$} & -.3498 & -.0637 & $1.3978^{\star}$ & $1.4156^{\star}$ \\
\hline & $(.373)$ & $(.387)$ & $(.726)$ & $(.720)$ \\
\hline \multirow[t]{2}{*}{ Media attention $_{t-1}$} & -.0650 & .0740 & -.4668 & -.4632 \\
\hline & $(.383)$ & $(.390)$ & $(.738)$ & $(.740)$ \\
\hline \multirow[t]{2}{*}{ Time trend } & $-.0014^{*}$ & -.0011 & -.0007 & -.0006 \\
\hline & $(.001)$ & $(.001)$ & $(.001)$ & $(.001)$ \\
\hline \multirow[t]{2}{*}{ Constant } & -.0190 & -.0580 & $.3817^{\star}$ & $.3703^{\star}$ \\
\hline & $(.113)$ & $(.116)$ & $(.222)$ & $(.218)$ \\
\hline$F$ & 3 & 3 & 2 & 2 \\
\hline$R^{2}$ & .377 & .338 & .303 & .303 \\
\hline Log likelihood & 177.547 & 174.570 & 111.514 & 111.489 \\
\hline $\mathrm{BIC}$ & -277.150 & -271.195 & -145.083 & -145.034 \\
\hline
\end{tabular}

Note. Standard errors in parentheses. MIP $=$ most important problem; GDP $=$ gross domestic product; $\mathrm{BIC}=$ Bayesian information criterion $. N=98$. ${ }^{*} p<.1$.

$* * p<.05$.

$* * * p<.01$. 
opposition parties to highlight either the most salient issue (i.e., amplified by the media) or the issue for which the incumbent has low competence (i.e., high unemployment and low growth), both early and late in the cycle. If one accepts that opposition parties interpret the issues highlighted by the media as a reflection of public opinion (since, in fact, our analyses show a relationship between negative economic evaluations and media attention), our findings are fully consistent with our expectations.

Figure $4 A$ illustrates the marginal effect of lagged opposition attention to the economy on government economic attention, conditional on time (Brambour, Clark, and Golder 2006). While the marginal effect is negative and significant at the beginning of the cycle (i.e., opposition party attention to economic issues tends to depress the attention paid by the governing party), it becomes positive and significant at the end of the cycle (i.e., opposition attention increases government attention). Figure $4 B$ illustrates the marginal effect of lagged aggregate MIP on government economic attention. The effect is positive and significant at the earliest point in the electoral cycle. However, the positive effect of public opinion on government economic attention experiences a slight monotonic decline over the electoral cycle, until it simply becomes statistically insignificant after the first nine months of the new electoral term (approximately the first parliamentary year of the new incumbency).

The findings presented in this section are consistent with the theoretical model described above. Our model predicted that early in an electoral cycle parties are better off highlighting the issue that is salient in public opinion. Our empirical findings confirm that this is true for governing parties, since public opinion is the only significant driver of government discourse at the beginning of the cycle. Even if the im- pact of MIP values on opposition rhetoric is insignificant, opposition parties talk about the economy when the media highlights news driven by bad macroeconomic conditions and public dissatisfaction. If one accepts media attention as a proxy for issue saliency, it is reasonable to believe that opposition parties echo negative economic news once these issues are salient in the public debate. The results shown in table 3 suggest a zero-sum game in which government responsiveness cannot be unlimited and tends to be more driven by endogenous party competition dynamics than by public opinion concerns as the next election comes closer. The results suggest an intuitive but nuanced story regarding government economic responsiveness. While issue ownership or selective issue emphasis theories rightly predict that parties will not engage in dialogue and will tend to put forward their agenda independent from one other at the beginning of the cycle, issue dialogue becomes a much more likely outcome as time progresses.

It is also true, however, that proposition 1.1 in our model was supposed to be valid when the government party is relatively competent in all issue domains. Our data only have four electoral cycles and do not allow us to test a four-way interaction between opposition discourse, economic issues, noneconomic issues, and the electoral cycle. In any case, our model does not imply that parties are perfectly aware of their relative competence across issues and party rivals, which renders the direct empirical test of different scenarios of crossissue competence ambiguous. However, our model also does not pretend to deterministically predict a dynamic empirical reality in which political actors need to make quick decisions without perfect information. Both our theory and empirical analysis still prove the intuition that, under certain conditions, some parties can engage in a dialogue with their competitors
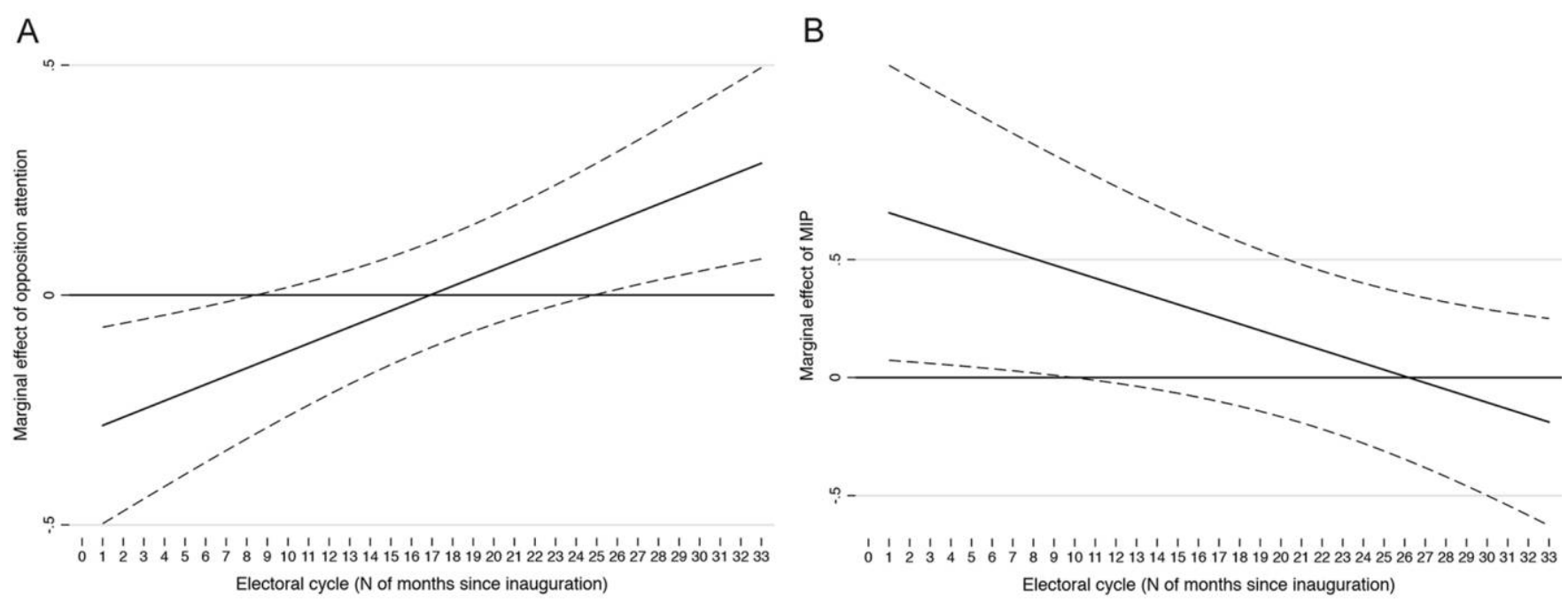

Figure 4. Marginal effects on government economic attention: $A$, opposition attention; $B$, most important problem 
while disregarding public opinion and that this only occurs at later stages in the electoral cycle.

The appendix shows a myriad of robustness checks and confirms that our main conclusions are not biased by serial correlation or nonstationarity concerns. ${ }^{16}$ The ADL models specified above include both the lagged dependent variable and a time trend, but the results are always consistent if these two terms are removed from the equation (tables 15 and 16 in app. 3). We also replicated our main models with electoral term fixed effects, showing that our models are robust to incumbency-specific unobservables and breaks potentially related to changes in parliamentary mechanics, party popularity, or discontinuous changes in economic conditions (tables 17 and 18 in app. 3). Even if no observational analysis is immune to unobserved confounders or reciprocal effects, our findings are compatible with a Granger causality perspective. While the lagged predictors of opposition attention affect government attention over the cycle, the lagged value of the incumbent does not affect the opposition (see tables 2 and 3). Similarly, MIP is not a function of lagged government discourse (table 8 in app. 3). Finally, when modeling nonparametrically the effects of our key predictors over time, kernel-weighted local polynomial regressions (app. 4) confirm the increasing and decreasing effects of opposition attention and MIP on government economic attention, respectively.

\section{CONCLUSION}

Understanding when and why parties decide to talk about some issues and not others is one of the cornerstones of

16. Tables 2 and 3 in app. 2 show the Durbin-Watson statistic, Durbin's alternative test, the Breusch-Pagan test, and the Portmanteau Q test for error autocorrelation relative to all the models reported in this section. While the Durbin-Watson tests are inconclusive (since they fall within the boundaries of their respective lower and upper critical values), Durbin's alternative test for serial correlation (which we make robust to the violation of the assumption of homoscedasticity) is more reassuring (in all cases but one). If we rely on the stricter Portmanteau Q test of the model residuals for autocorrelation beyond order 1, the results are particularly reassuring: in all cases, we fail to reject the hypothesis that our model residuals are a white noise process. Finally, the only unsatisfactory results concern the Breusch-Pagan test for the models predicting opposition attention, since they cannot clearly reject that the residuals follow a heteroscedastic pattern. Despite this one result not fitting the overall pattern of normality in the residuals according to the other tests, our main substantive conclusions regarding the electoral cycle are based on models predicting government attention, which are entirely satisfactory. Table 4 in app. 2 reports a series of Dickey-Fuller tests clearly rejecting the null hypothesis of a unit-root process for government attention to the economy, opposition attention to the economy, GDP growth, MIP, and media attention. Only two independent variables marginally failed the test, namely, public economic evaluations and unemployment. Despite none of these variables being critical to our conclusions regarding the electoral cycle, tables 9 and 10 in app. 2 satisfactorily replicate our main findings while including the first difference (i.e., strictly stationary) of those variables in the model. democratic representation. The issue of the economy is particularly relevant in this respect, given the enormous academic attention that it has gathered and its remarkable effects on electoral results. The literature on issue competition has come up with solid but contradictory theoretical frameworks. While issue ownership or issue emphasis theories predict that parties will highlight only those issues that are beneficial to them, issue dialogue theories predict that under some circumstances parties will follow public opinion concerns or will respond to other parties and the media, even on issues that are not particularly beneficial to them.

In this article we have proposed a model in which parties expect voters to myopically react to recent events and in which the cost of the main opponent gaining economic reputation is perceived to be high as proximity to election day increases. More specifically, we hypothesized that governing parties are more likely to respond to public opinion earlier in the election cycle but that the incentives to respond to opposition attacks (even at the cost of provisionally ignoring public opinion) increase as the election approaches. Moreover, our model revealed that, in a relevant number of scenarios, opposition parties are better off highlighting salient issues that can harm the incumbent, at both early and late stages in the electoral cycle.

Our ADL models empirically confirmed the main intuitions of our model and revealed the timeline of issue competition: a rise in unemployment and a decline in GDP growth increases negative views on the national economy in public opinion, which increases media attention to the economy. Subsequently, media economic attention increases the challenger's economic attention at any point in the electoral cycle. Governing parties, however, are more likely to respond to those uncomfortable opposition attacks only toward the end of the electoral cycle and to forget public opinion as the pressure from the opposition increases. Our analyses also revealed small but significant long-term effects of GDP growth increasing government economic attention, which is an intuitive result consistent with classical issue ownership expectations.

Our findings shed light on some contradictions between proponents of issue ownership and issue dialogue theories. Both seem to be conditional on time and on whether a party is in or out of power. Issue ownership is consistent with the long-term effect of GDP growth on government attention and the indirect effect of unemployment and GDP on the opposition (via negative economic evaluations and the media; Petrocik 1996; Vavreck 2009). However, incumbents have fewer incentives to engage in endogenous patterns of party competition at the beginning of the cycle (issue ownership), but they feel a significantly stronger pressure to respond to attacks as election day approaches (issue dialogue). This confirms the 
increasing importance of focusing on government opposition dynamics when analyzing policy agendas (Seeberg 2013; Thesen 2013).

Our findings also highlight a pessimistic outcome for ideal conceptions of bottom-up processes of representation. Public opinion is not a clear driver of opposition parties' issue agenda, and it only seems to drive the government's communication strategy on economic issues at the beginning of the electoral cycle. This is consistent with the idea that countries with higher levels of decentralization and devolution (e.g., Spain) will experience a weaker link between public opinion concerns and policy outputs (John, Bevan, and Jennings 2011). However, our results also point out that the link between public opinion and government agendas can weaken even in countries that have relatively high levels of clarity surrounding executive responsibility, few coalition governments, and a low number of veto players (Bevan and Jennings 2014). The variability of incentives for parties to follow or ignore public opinion over a single electoral cycle seems to transcend some of the static implications of the current literature that assesses the effect of institutional settings on issue responsiveness. Overall, these findings unpack an important mechanism whereby office-seeking dynamics may exacerbate the increasing sense of detachment between some sectors in public opinion and mainstream politicians.

\section{ACKNOWLEDGMENTS}

Earlier versions of this article were presented at the 2014 Annual Conference of the European Political Science Association in Edinburgh and the 2014 General Conference of the European Consortium for Political Research in Glasgow, as well as in research seminars at the University of Barcelona, Pompeu Fabra University, University of Aarhus, and University of Geneva. We are grateful to audiences and discussants for their comments. We would particularly like to thank Bassel Tarbush, Laron Williams, three anonymous reviewers, as well as the comparative politics editor of the Journal of Politics, Lanny Martin, for comments, suggestions, and constructive criticisms.

\section{REFERENCES}

Alvarez, R. Michael. 1997. Information and Elections. Ann Arbor: University of Michigan Press.

Ansolabehere, Stephen, and Shanto Iyengar. 1994. "Riding the Wave and Claiming Ownership over Issues: The Joint Effects of Advertising and News Coverage in Campaigns." Public Opinion Quarterly 58 (3): 335-57.

Arceneaux, Kevin. 2008. "When Issues Are Ripe for the Taking: Policy Performance, Issue Ownership, and Issue Trespassing." Working paper.

Austin, Hart. 2013. "Can Candidates Activate or Deactivate the Economic Vote? Evidence from Two Mexican Elections.” Lournal of Politics 75 (4): 1051-63.
Bartels, Larry. 2008. Unequal Democracy: The Political Economy of the New Gilded Age. Princeton, NJ: Princeton University Press.

Baumgartner, Frank R., Bryan D. Jones, and Beth L. Leech. 1997. "Media Attention and Congressional Agendas." In Shanto Iyengar and Richard Reeves, eds., Do the Media Govern? Politicians, Voters and Reporters in America. Thousand Oaks, CA: Sage, 349-63.

Bélanger, Éric, and Bonnie Meguid. 2008. "Issue Salience, Issue Ownership, and Issue-Based Vote Choice." Electoral Studies 27 (3): 477-91.

Bélanger, Éric, and Richard Nadeau. 2014. "Economic Crisis, Party Competence and the Economic Vote." Acta Politica 49 (4): 462-85.

Bélanger, Éric, and Richard Nadeau. 2015. "Issue Ownership of the Economy: Cross-Time Effects on Vote Choice.” West European Politics 38 (4): 909-32.

Bevan, Shaun, and Will Jennings. 2014. "Representation, Agendas and Institutions." European Journal of Political Research 53 (1): 37-56.

Brambour, Thomas, William Roberts Clark, and Matt Golder. 2006. "Understanding Interaction Models: Improving Empirical Analyses.” Political Analysis 14 (1): 63-82.

Budge, Ian, and Michael Laver. 1993. "The Policy Basis of Government Coalitions: A Comparative Investigation." British Journal of Political Science 23 (4): 499-519.

Chaqués-Bonafont, Laura, and Frank R. Baumgartner. 2013. "Newspaper Attention and Policy Activities in Spain.” Lournal of Public Policy 33 (1): 65-88.

Chaqués-Bonafont, Laura, Anna Palau, and Frank R. Baumgartner. 2014. Policy Dynamics in Spain. London: Palgrave.

Christiansen, Flemming Juul, and Henrik Bech Seeberg. 2016. "Cooperation between Counterparts in Parliament from an Agenda-Setting Perspective: Legislative Coalitions as a Trade of Criticism and Policy." West European Politics 39 (6): 1160-80.

Corchón, Luis. 2007. “The Theory of Contests: A Survey.” Review of Economic Design 11:69-100.

De Boef, Suzanna, and Luke Keele. 2008. “Taking Time Seriously.” American Journal of Political Science 52 (1): 184-200.

Duch, Raymond M., and Randolph T. Stevenson. 2008. The Economic Vote: How Political and Economic Institutions Condition Election Results. Cambridge: Cambridge University Press.

Egan, Patrick J. 2013. Partisan Priorities: How Issue Ownership Drives and Distorts American Politics. New York: Cambridge University Press.

Gelman, Andrew, and Gary King. 1993. "Why Are American Presidential Election Campaign Polls So Variable When Votes Are So Predictable?" British Journal of Political Science 23 (4): 409-51.

Green, Jane, and Will Jennings. 2017a. "Party Reputations and Policy Priorities: How Issue Ownership Shapes Executive and Legislative Agendas." British Journal of Political Science (forthcoming).

Green, Jane, and Will Jennings. 2017b. The Politics of Competence: Parties, Public Opinion and Voters. Cambridge: Cambridge University Press.

Green-Pedersen, Christoffer, and Peter Mortensen. 2010. "Who Sets the Agenda and Who Responds To It in the Danish Parliament?" European Lournal of Political Research 49 (2): 257-81.

Green-Pedersen, Christoffer, and Peter Mortensen. 2014. "Avoidance and Engagement: Issue Competition in Multiparty Systems.” Political Studies 63 (4): 747-64.

Green-Pedersen, Christoffer, and Rune Stubager. 2010. "The Political Conditionality of Mass Media Influence: When Do Parties Follow Mass Media Attention?" British Journal of Political Science 40 (3): 663-77.

Green-Pedersen, Christoffer, and Stefaan Walgrave, eds. 2014. AgendaSetting, Policies and Political Systems. Chicago: University of Chicago Press.

Hellwig, Timothy, and Dani M. Marinova. 2014. "More Misinformed than Myopic: Economic Retrospections and the Voter's Time Horizon." Political Behavior 37 (4): 865-87. 
Jennings, Will, and Christopher Wlezien. 2011. "Distinguishing between Most Important Problems and Issues?" Public Opinion Quarterly 75 (3): $545-55$.

Jennings, Will, and Christopher Wlezien. 2016. "The Timeline of Elections: A Comparative Perspective." American Journal of Political Science 60 (1): 219-33.

John, Peter, Shaun Bevan, and Will Jennings. 2011. "The Policy-Opinion Link and Institutional Change: The Legislative Agenda of the UK and Scottish Parliaments." Journal of European Public Policy 18 (7): 1052-68.

Kaplan, Noah, David Park, and Travis Ridout. 2006. "Dialogue in American Political Campaigns? An Examination of Issue Convergence in Candidate Television Advertising." American Journal of Political Science 50 (3): 724 36.

Klüver, Heike, and Iñaki Sagarzazu. 2016. "Setting the Agenda or Responding to Voters? Explaining Selective Issue Emphasis of Political Parties." West European Politics 39 (2): 380-98.

Maltzman, Forrest, and Lee Sigelman. 1996. "The Politics of Talk: Unconstrained Floor Time in the U.S. House of Representatives." Journal of Politics 5 (8): 810-21.

Martin, Lanny, and Georg Vanberg. 2008. "Coalition Government and Political Communication.” Political Research Quarterly 61 (3): 502-16.

Pardos-Prado, Sergi, and Iñaki Sagarzazu. 2016. "The Political Conditioning of Subjective Economic Evaluations: The Role of Party Discourse." British Journal of Political Science 46 (4): 799-823.

Petrocik, John. 1996. "Issue Ownership in Presidential Elections, with a 1980 Case Study." American Journal of Political Science 40 (3): 825-50.

Popkin, Samuel. 1991. The Reasoning Voter: Communication and Persuasion in Presidential Campaigns. Chicago: University of Chicago Press.

Robertson, David. 1976. Theory of Party Competition. New York: Wiley.

Sagarzazu, Iñaki, and Heike Klüver. 2017. "Coalition Governments and Party Competition: Political Communication Strategies of Coalition Parties." Political Science Research and Methods 5 (2): 147-75.

Seeberg, Henrik Bech. 2013. “The Opposition's Policy Influence through Issue Politicisation." Journal of Public Policy 33 (1): 89-107.

Sides, John. 2006. "The Origins of Campaign Agendas." British Journal of Political Science 36 (3): 407-36.

Sigelman, Lee, and Emmett Buell. 2004. "Avoidance or Engagement? Issue Convergence in U.S. Presidential Campaigns, 1960-2000.” American Journal of Political Science 48 (4): 650-61.

Simon, Adam F. 2002. The Winning Message. Cambridge: Cambridge University Press.

Slapin, Jonathan B., and Sven-Oliver Proksch. 2014. The Politics of Parliamentary Debates. Cambridge: Cambridge University Press.

Soroka, Stuart N. 2002. Agenda-Setting Dynamics in Canada. Vancouver: University of British Columbia Press.

Spoon, Jae-Jae, and Heike Klüver. 2015. "Voter Polarization and Party Responsiveness: Why Parties Emphasize Divided Issues, but Remain
Silent on Unified Issues." European Journal of Political Research 54 (2): $343-62$.

Sulkin, Tracy. 2005. Issue Politics in Congress. Cambridge: Cambridge University Press.

Thesen, Gunnar. 2013. "When Good News Is Scarce and Bad News Is Good: Government Responsibilities and Opposition Possibilities in Political Agenda-Setting." European Journal of Political Research 52 (3): 364-89.

Tullock, Gordon. 1980. "Efficient Rent-Seeking." In James M. Buchanan, Robert D. Tollison, and Gordon Tullock, eds., Towards a Theory of a Rent-Seeking Society. College Station: Texas A\&M University Press, 97-112.

Van Aelst, Peter, and Rens Vliegenthart. 2014. "Studying the Tango." Journalism Studies 15 (4): 392-410.

van der Brug, Wouter, Cees van der Eijk, and Mark Franklin. 2007. The Economy and the Vote: Economic Conditions and Elections in Fifteen Countries. Cambridge: Cambridge University Press.

Vavreck, Lynn. 2007. "The Exaggerated Effects of Advertising on Turnout: The Dangers of Self-Reports." Quarterlv Journal of Political Science 2 (4): 325-43.

Vavreck, Lynn. 2009. The Message Matters: The Economy and Campaign Effects in Presidential Elections. Princeton, NJ: Princeton University Press.

Vliegenthart, Rens, and Stefaan Walgrave. 2011. "Content Matters: The Dynamics of Parliamentary Questioning in Belgium and Denmark." Comparative Political Studies 44 (8): 1031-59.

Vliegenthart, Rens, Stefaan Walgrave, Frank R. Baumgartner, Shaun Bevan, Christian Breunig, Sylvain Brouard, Laura Chaqués Bonafont, Emiliano Grossman, Will Jennings, Peter B. Mortensen, Anna M. Palau, Pascal Sciarini, and Anke Tresch. 2016. "Do the Media Set the Parliamentary Agenda? A Comparative Study in Seven Countries." European Journal of Political Research 55 (2): 283-301.

Walgrave, Stefaan, Stuart Soroka, and Michiel Nuytemans. 2008. "The Mass Media's Political Agenda-Setting Power: A Longitudinal Analysis of Media, Parliament, and Government in Belgium, 1993 to 2000." Comparative Political Studies 41 (6): 814-36.

Walgrave, Stefaan, and Peter Van Aelst. 2006. "The Contingency of the Mass Media's Political Agenda Setting Power: Toward a Preliminary Theory." Journal of Communication 56 (1): 88-109.

Wanta, Wayne, and Joe Foote. 1994. "The President-News Media Relationship: A Time Series Analysis of Agenda-Setting." Journal of Broadcasting and Electronic Media 38 (4): 437-51.

Williams, Laron K. 2013. "Flexible Election Timing and International Conflict." International Studies Quarterly 57 (3): 449-61.

Williams, Laron K., Kastsunori Seki, and Guy D. Whitten. 2015. "You've Got Some Explaining to Do: The Influence of Economic Conditions and Spatial Competition on Party Strategy." Political Science Research and Methods 4 (1): 47-63.

Wlezien, Christopher. 2005. "On the Salience of Political Issues: The Problem with “Most Important Problem.'” Electoral Studies 24 (4): 555-79. 